\title{
Development of a fish-based index combining data from different types of fishing gear. A case study of reservoirs in Flanders (Belgium)
}

\author{
Jan Breine ${ }^{1, *}$, Gerlinde Van Thuyne ${ }^{1}$ \& Luc De Bruyn ${ }^{2}$
}

\begin{abstract}
1 Research Institute for Nature and Forestry, Duboislaan 14, B-1560 Groenendaal, Belgium. E-mails: jan.breine@inbo.be, gerlinde.vanthuyne@inbo.be

2 Research Institute for Nature and Forestry, Kliniekstraat 25, B-1070 Brussels, Belgium and Evolutionary Ecology, Department of Biology, University of Antwerp, Groenenborgerlaan 171, B-2020 Antwerpen, Belgium. E-mail: luc.debruyn@inbo.be
\end{abstract}

* Corresponding author: jan.breine@inbo.be

\begin{abstract}
Fish assemblages in reservoirs and lakes are mainly assessed by multiple sampling gear. The challenge exists in how to combine all the data from the different types of gear to develop a fish-based index. In this paper, we describe a novel approach to this challenge in reservoirs in Flanders. The developed approach can also be used for natural lakes in the same eco-region and for any combination of fishing methods. In a first step, we defined a reference list of fish species occurring in man-made Flemish reservoirs. To compile this reference list, we adapted the reference for Dutch lakes with recent data from freshwater reservoirs in Flanders. This reference list contains guild-specific information needed to define metrics. To pre-classify the reservoirs, a habitat status for each reservoir was set using abiotic parameters (pressures). Fish gear-dependent metrics were selected according to their response to these pressures. Threshold values for metrics were determined based on the species reference list and occasionally on the calculated metric values. The ecological quality ratios derived from the index calculation were validated with an independent set of data. The developed index proved to successfully assess the ecological status of the reservoirs in Flanders.
\end{abstract}

KEY WORDS: fish reference list, fish-based index, modelling, monitoring, European Water Framework Directive.

\section{INTRODUCTION}

The most effective way to define the ecological status of lakes and reservoirs is to assess their vegetation and fauna (LYCHESolHEIM et al., 2013). Advantages of biological monitoring are well known and this is one of the reasons phytoplankton, macrophytes, benthic invertebrates and fish are suggested by the European Water Framework Directive (WFD) as biological quality elements to assess the integrity of lakes and reservoirs (EU WATER FRAMEWORK DiRECTIVE, 2000). In Europe, fish-based indices became important bio-assessment tools since the implementation of this directive. Some researchers in Europe assessed the suitability of fish communities in lakes and reservoirs to indicate anthropogenic deterioration (e.g. APPELBERG et al., 2000; CAROL et al., 2006; GARCIA et al., 2006). As a consequence, fish-based indices were developed to assess the ecological quality of lakes (BELPAIRE et al., 2000; HolmGREN et al., 2007; BECK \& HATCH, 2009; WIŚNIEWOLSKI \& PRUS, 2009; LAUNOIS et al., 2011a; ARGILLIER et al., 2013) and reservoirs (CATALAN \& VENTURA, 2003). A fish-based index is a multimetric procedure to assess the biotic integrity of aquatic ecosystems (KARR, 1981). A metric is a variable assessing an ecological attribute of a community that is sensitive to human impact and reacts unambiguously to impact changes (BREINE et al., 2010). Unfortunately, the majority of lake indices have been based on standardised procedures with stratified multi-mesh gillnet fishing only (CEN, 2005). Another difficulty with the earlier fishbased indices concerned the heterogeneity of the 
survey methods. Some indices were developed using different fishing techniques without considering the gear specificity (e.g. BELPAIRE et al., 2000; BACKX et al., 2008). These indices have to be used with caution. Indeed CHOW-FRASER et al. (2006) observed that, although electric fishing and fyke netting each caught $60 \%-75 \%$ of the species present in a wetland, particular species and dominant functional groups tended to be gear specific. Still, metric responses to stress can be developed but patterns of response to particular anthropogenic pressures are unique to gear type (CHOW-FrASER et al., 2006). It is hence important to develop an index combining gear-specific metrics as it is the only effective ecological status assessment method integrating ecological, functional and structural aspects of aquatic systems.

Another crucial step in the development of a fish-based index is the realisation of a reference fish assemblage. Many lakes in Europe were identified as artificial or heavily modified water bodies (HMWB), the latter because their nature has changed fundamentally as a result of physical anthropogenic alterations. According to Article 4(3) of the WFD the principal environmental objective for HMWB and artificial water bodies, such as reservoirs, is to obtain a "good ecological potential" (GEP) instead of a "good ecological status" as required for natural systems. Similarly, the reference situation in HMWB is referred to as "maximal ecological potential" (MEP) instead of a "pristine status" (EU WATER FRAMEWORK DiRective, 2000). According to WFD, the MEP biological conditions should reflect the biological conditions associated with the closest comparable natural water body type at reference conditions as far as possible, given the MEP's hydromorphological and associated physical and chemical conditions. For an HMWB to be classified as attaining GEP status no more than slight changes in the values of the relevant biological quality elements may be observed as compared to their values at MEP. GEP thus represents a state in which the ecological potential of a water body is falling only slightly short of the maximum it could achieve without significant adverse effects on the wider environment or on the relevant water use or uses (CWD, 2012). As a result the species list is the same for both MEP and GEP and they only differ in threshold values of the selected metrics. The biological potential can be defined once the hydromorphological, physical and chemical potentials are described.

As mentioned by LAUNOIS et al. (2011a) problems can arise in establishing a reference condition due to the lack of pristine lakes. Hence, we provide a reference condition approach that can be used for any kind of water type.

In this study we describe a new approach to develop a fish-based index combining data obtained from different types of fishing gear. As a case study we used data from reservoirs in Flanders. The proposed methodology is straightforward and can be used with any kind of data and water types.

\section{MATERIALS AND METHODS}

\section{Study area}

The study area comprised 26 reservoirs located in Flanders $\left(13.521 \mathrm{~km}^{2}\right)$ (Fig. 1). They were selected because they are incorporated into the Flemish freshwater fish-monitoring network. Only some reservoirs are connected to a river (river fed, see Table A, annex).

The surface area of the 26 reservoirs varies between 0.14 and 99 ha with an average depth ranging from 0.5 to $18.5 \mathrm{~m}$ (Table $\mathrm{A}$, annex). According to criteria described by LEWIS (1983), all reservoirs could be considered as polymictic. In addition, nine reservoirs were selected for validation purposes (Fig. 1). Pressure values were calculated as the sum of scores for industry, agriculture activity (any including ploughing activities, grassland,...) and development constructions (number of houses); the investigated adjacent area extended $100 \mathrm{~m}$ inland from the banks as most reservoirs have no catchment or only small brooks feeding into 
them. Data were recorded in the field or via Google Earth when data were missing. Industry (presence of industrial activities e.g. factories) was scored as present (1) or not (0). Thresholds for agriculture activity and development were: 1 if less than $10 \%$ of the area is used; $2=\leq 30$ $\geq 10 \% ; 3=\leq 50->30 \%$; and 4 if more than $50 \%$ is used. We also assessed the natural state score of the banks: $1=100 \%$ natural, $2=25 \%$ or less of the bank surface is reinforced (concrete, stones etc.), 3 = between 25 and $50 \%$ is reinforced, and $4=$ more than $50 \%$ is unnatural. The total pressure was obtained by summing all pressure scores and can vary between 3 and 13. A pressure class (status) was defined as follows: good or high $=3$; moderate $=4$; poor $>4$ and $\leq 8$ and bad $>9$. Presence of trees was assessed as a predictor, recorded as percentage of area coverage and scored as follow: 4 (no trees); $3=\leq 10 \% ; 2=$ $>10 \leq 50 \%$ and $1=$ more than $50 \%$ of the area covered with trees.

\section{Fish data}

All field work was performed by trained fish biologists and technicians using the protocol described in BelPAIRE et al. (2000). Surveys occurred in autumn between 1996 and 2005 (development data) and between 2006 and 2012 (independent validation data). Fish assemblage data were obtained by electric fishing from a boat with two hand-held anodes, using a $5 \mathrm{~kW}$ generator with an adjustable output voltage of 300 to $500 \mathrm{~V}$ and a pulse frequency of $480 \mathrm{~Hz}$. We surveyed on average $266 \mathrm{~m}$ (range: $25-2100$ $\mathrm{m}$; average width $2.5 \mathrm{~m}$ ) long shore transects per ha with electric gear. The variability in effort is due to the fact that no standardised method was defined before the year 2000. At least four paired-fyke nets ( $90 \mathrm{~cm}$ diameter and $22 \mathrm{~m}$ long) were placed per reservoir for two successive days (48h) with, on average, one paired-fyke net per hectare (Table A, annex). Fish data recorded

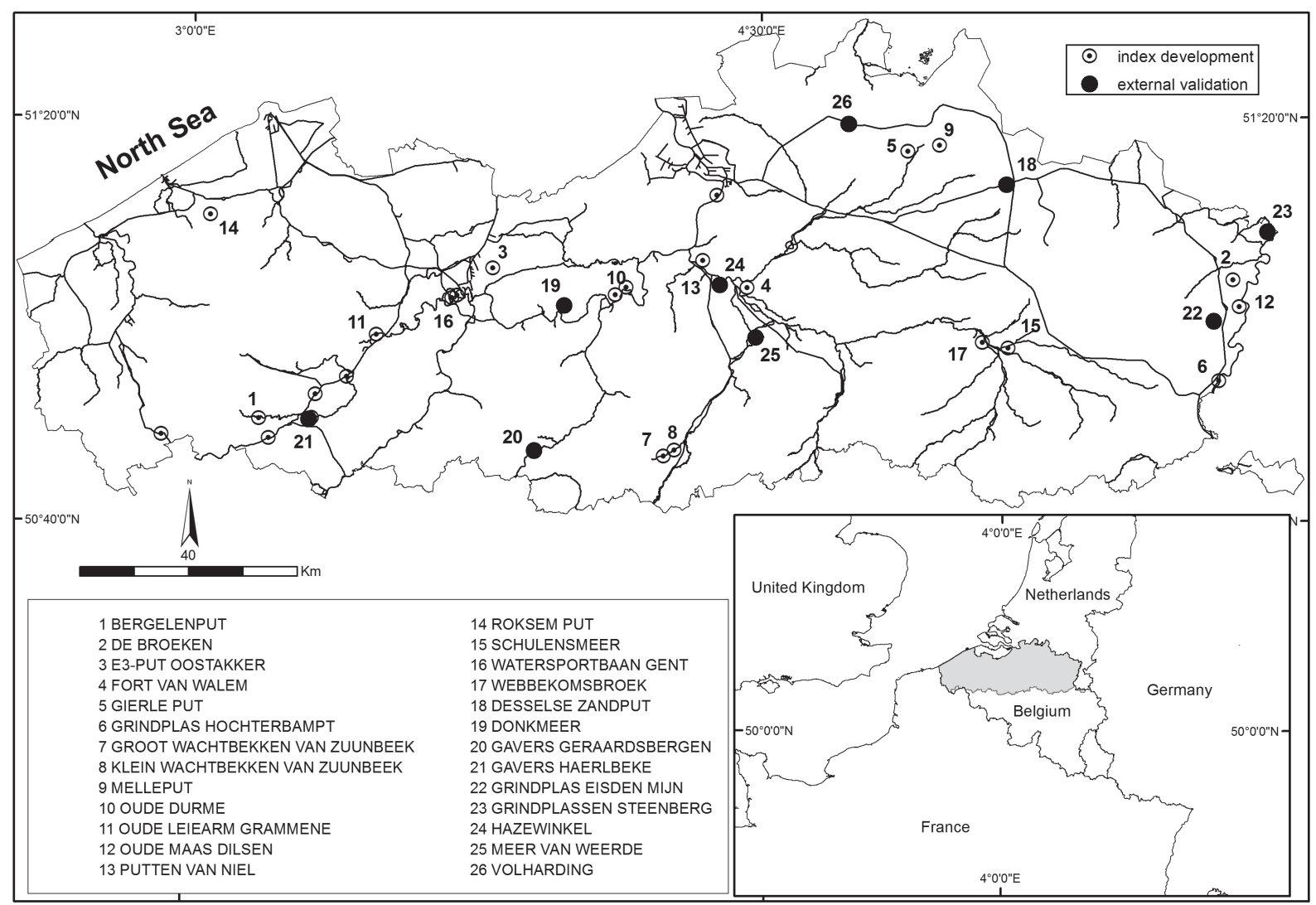

Fig. 1 - Overview of assessed reservoirs (1996-2005) and reservoirs used for the external validation (20062011) in Flanders, Belgium. 
include species-specific fish densities, individual total lengths (TL, nearest $0.1 \mathrm{~cm}$ ) and wet weights (nearest $0.1 \mathrm{~g}$ ).

Data are available from the Fish Information Database (VIS databank: http://vis.milieuinfo. be).

\section{Species reference list}

We adapted the reference species list described by BACKX et al. (2008) for the Dutch lakes with Flemish data from surveys for the period 19962005. We omitted species from the MEP/GEP list even if they previously occurred in a particular reservoir when: 1) fish are locally or regionally extirpated or 2) a reservoir or lake is not their preferred habitat (RAMM, 1990).

Exotic species were defined according to VERREYCKEN et al. (2007). The classification of species as 'native' and 'non-indigenous' was based on historical and archaeological records. All exotic species were omitted from the list as many authors (e.g. KARR, 1981; BELPAIRE et al., 2000) consider these as indicators of disturbance. Exceptions are pike-perch (Sander lucioperca, Linnaeus, 1758), common carp (Cyprinus carpio, Linnaeus, 1758) and Prussian carp (Carassius gibelio, Bloch, 1782) as they can be considered as naturalised. Moreover, pike-perch has a high oxygen demand (MARSHALL, 1977; FAO, 1984, 1989); hence, the species' presence is an indicator for good water quality.

\section{Index development}

Fish were attributed to guilds based on a literature review (BREINE et al., 2004, 2005). Species were categorised according to their tolerance for oxygen deficiency and habitat structure degradation such as shoreline bank modifications. Tolerance scores for oxygen deficiency and structural habitat modifications, from 1 (tolerant) to 5 (intolerant), were given to each species based on information from
BelPAiRe et al. (2000) and BREINE et al. (2007). Ecologically-relevant candidate metrics were selected from literature (BELPAIRE et al., 2000; JEPPESEN et al., 2000; MEHNER et al., 2004; GARCIA et al., 2006; JAARSMA, 2007; LAUNOIS et al., 2011b). For each reservoir, gear-specific metric values were calculated using reference species only (BREINE et al., 2010). To correct for differences in sampling effort, catch per unit effort (CPUE) was used i.e. survey data were standardised to catch results per $\mathrm{m}^{2}$ (electric fishing) and catch per fyke day (number of fish per fyke per day).

\section{Statistical analyses}

To retrieve less-skewed distribution, percentage metrics were square-root transformed and count metrics were $\log$-transformed $(\log x+1)$ (LAUNOIS et al., 2011b). Diversity metrics were not transformed.

First the correlation among pressure scores was assessed (measure of association, $p$ (Fisher)) to avoid co-linearity. Pearson correlation was applied to assess correlation between reservoir depth and reservoir surface $(\log \mathrm{x}+1)$ transformed values.

The response of metrics to pressures (log transformed values to meet requirements of linear models) and predictors (depth, surface, trees) was analysed with linear mixed regression models. As some locations were sampled several times we added locality and year as random effects. We started with a full model including all pressures and predictors. We applied a stepwise backward selection until only significant terms remained. Normality assumptions were assessed with residual plots. To define the goodness-offit, the marginal and conditional $\mathrm{R}^{2}$ values for each fitted model were calculated as described by NAKAGAWA \& SCHIELZETH (2013). Only the metric response to pressures was decisive for the selection $\left(\mathrm{R}^{2}\right.$ conditional $\left.>35 \%\right)$. Redundancy of responsive metrics was analysed with a Pearson correlation. To choose among the correlated 
metrics ( $\geq 0.7 ; p \leq 0.001$ ), the one with the best fitted model was taken. Secondly, among the less correlated metrics ( $c<0.7$ and $\geq 0.5 ; p \leq 0.05)$, the one that least correlated with other metrics was selected.

The statistical software used was R.2.15.2 packages lme4, nlme and MuMIn (R DEVELOPMENT CORE TEAM, 2012).

Threshold value determination for the selected metrics was based on the reference list and followed BREINE et al. (2010). Once the GEP was defined the other integrity classes were defined by applying trisection with GEP values.

For the relative percentage metrics (Mpi metrics) the GEP is the ratio of the number of the species included in a particular Mpi metric over the total number of species in the reference list (BREINE et al, 2010).

For metrics assessing number of species $60 \%$ of the reference number was taken as the GEP status threshold value, while this was $80 \%$ for the metric tolerance value.

The average value from the highest impacted sites was used to define the minimum percentage weight of benthivorous species (BenWei) and the bream (Abramis brama, LinNAEUS, 1758) and roach (Rutilus rutilus, LINNAEUS, 1758) associated metric (AbrRut).

The sum of the metric scores obtained with each method gave the index of biotic integrity (IBI) score for a particular reservoir. To comply with the WFD, this score was transformed to an ecological quality ratio (EQR) calculated as a value between 0 and $1: \mathrm{EQR}=(\mathrm{IBI}$-lowest IBI possible)/(maximum IBI possible - lowest IBI possible). The EQR for the MEP status is 1 under which four integrity classes are defined: GEP (lower threshold value 0.75 ), moderate $(0.5)$, poor $(0.25)$ and bad $(<0.25)$. The transformation to equal interval classes was obtained using the following formula for each integrity interval (piecewise transformation):

$$
\begin{gathered}
\mathrm{T} E \mathrm{EQR}=\mathrm{LV} \text { T EQR + (O EQR - LV O EQR }) / \\
(\mathrm{UV} \mathrm{O} \mathrm{EQR}-\mathrm{LV} \mathrm{O} \mathrm{EQR}) * 0.25
\end{gathered}
$$

$\mathrm{O}$ and $\mathrm{T}$ stand for original and transformed EQR value, UV and LV (upper and lower value of integrity class). When, during one campaign, more than one site was assessed within one reservoir, data obtained with the same method were summed and transformed to catch per unit effort (i.e. per $\mathrm{m}^{2}$ or per fyke day) to calculate the final EQR for the reservoir. Selected metrics were graphically screened with boxplots to assess the response to pressure. Allowing a class difference of one unit (see BREINE et al., 2007, 2010), indices were validated by comparing the integrity class obtained per reservoir with its assessed pressure status. We assessed data of reservoirs used for the index development and an independent set of data consisting of fish data from nine reservoirs not included in the index development (surveys in 2006-2012). Finally a comparison was performed between the EQR values obtained with the old (BELPAIRE et al., 2000) and new indices (Pearson correlation, boxplot). To allow comparison, the old EQR values for each fishing sample within one year in a particular reservoir were averaged.

\section{RESULTS}

The selected reservoirs have different morphological characteristics and are subjected to different degrees of pressures (Table A, annex). The scores of the pressure assessment ranged between 4 and 8 (moderate and poor status). None of the assessed reservoirs seemed to have a good or high habitat-status (pressure score $=3)$.

In total 28 fish species were caught in reservoirs between 1996 and 2005. Eel (Anguilla anguilla, LinNAEUS, 1758) and perch (Perca fluviatilis, LINNAEUS, 1758) were the most frequently caught species with fyke nets and electric fishing. Perch and ruffe (Gymnocephalus cernua, LINNAEUS, 1758) constituted the highest number of individuals caught with fyke nets, while roach and perch were most abundant during electric 


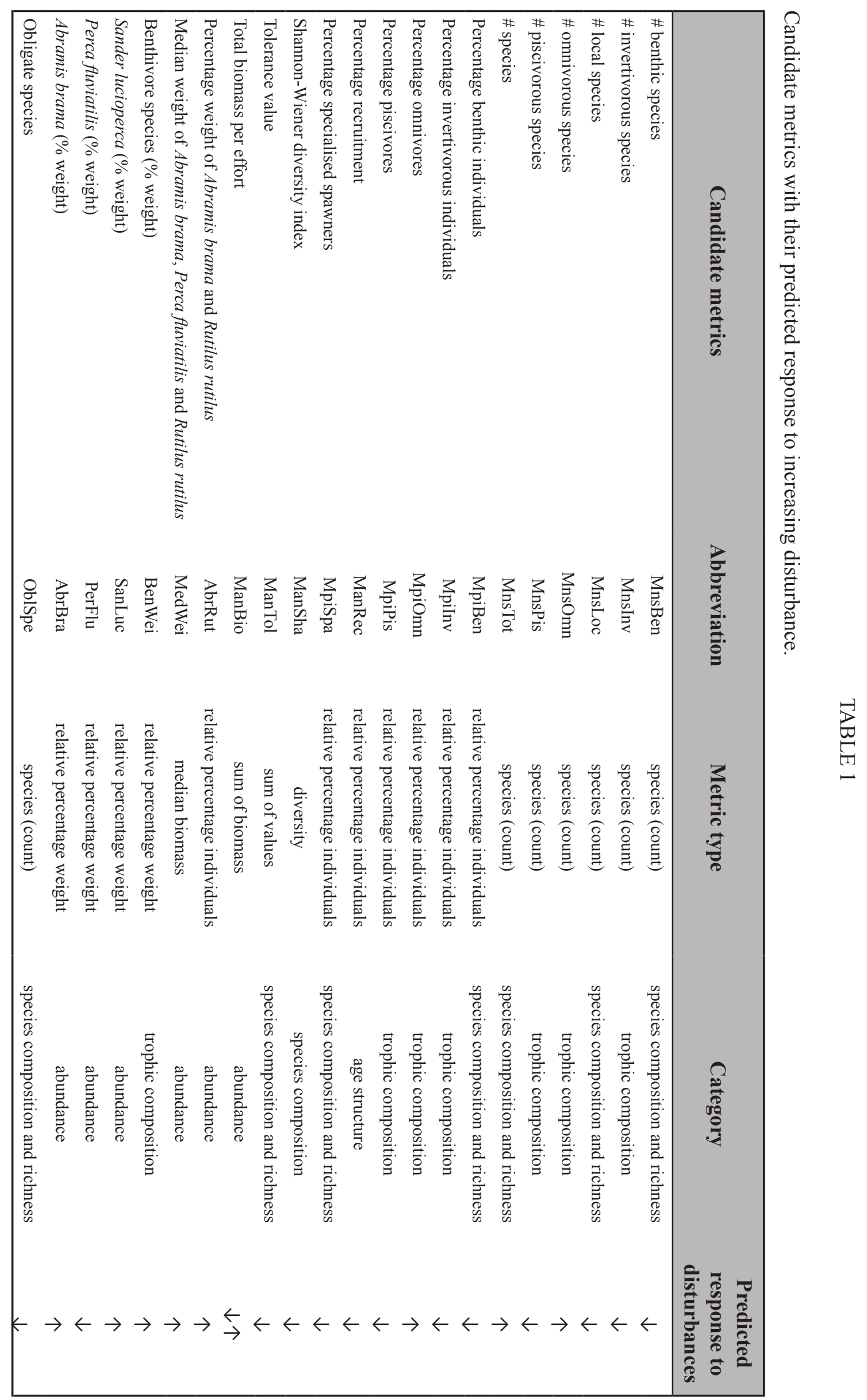


fishing (Table B, annex). Twenty-one species were selected to occur in the reference (MEP/ GEP) list, and guilds were attributed to the species included in this list (Table $\mathrm{C}$, annex). A total of 22 candidate metrics were selected (Table 1).

The measure of association analyses allowed the selection of uncorrelated pressure variables to be used in the model. Only agricultural and industrial activities were correlated $(\mathrm{V}=0.7 ; \mathrm{p}=$ 0.003). Agricultural activities were selected as they affect water quality by the use of fertilisers and pesticides and because of their effects on soil erosion. Reservoir surface and depth were not correlated (Pearson $c=0.159 ; \mathrm{p}=0.382$ ) and could be included in the model. The linear mixed model results are given in Table 2. For electric fishing data, seven metrics showed a significant relationship with the pressures and four with one of the descriptors. For the fyke net data, five candidate metrics showed a significant relationship with one pressure and six with one or two of the descriptors. Metrics that were not fitted by the model were omitted. Correlations between fitted metrics are given in Table 3 .

To assess the ecological status with electric survey catches, two of the seven significant variables were selected (Table 4), more specifically 'relative percentage of specialised spawners' (individuals) (MpiSpa) and the 'relative percentage of invertivorous individuals' (MpiInv). For the fyke net data, four metrics were selected out of five possible candidates. These included the 'number of piscivorous species' (MnsPis), 'relative percentage of omnivorous individuals' (MpiOmn), 'relative weight percentage of benthivore species' (BenWei) and 'tolerance value' (ManTol). The response of the selected metrics to environmental pressures (pre-classification) is illustrated with boxplots showing how metric distribution changes along the pre-classification score (Fig. 2). Only one metric (MpiOmn) did not react well to increasing pressure. Compared to the other selected metrics the absolute values for its goodness-of-fit of the model ( $\mathrm{R}^{2}$ marginal and conditional) were smaller (Table 2).

We considered 21 species in the reference list to be attributed to the selected metrics (Table C, annex). Below we give a short description of how the MEP/GEP for the six selected metrics was defined:

\section{- Percentage specialised spawners (MpiSpa)} (electric data)

There were six species involved: pike (Esox lucius LINNAEUS, 1758), gudgeon (Gobio gobio LINNAEUS, 1758), burbot (Lota lota LINNAEUS, 1758), ruffe, rudd (Scardinius erythrophthalmus LINNAEUS, 1758) and tench (Tinca tinca LINNAEUS, 1758). The relative species frequency in the reference condition (all 21 reference species present) equalled $28.5 \%(6 / 21) * 100)$ and was taken as GEP. This metric was independent from depth and surface area (Table 2).

- Percentage of invertivorous individuals (MpiInv) (electric data)

Only three species were assessed: perch $(<13 \mathrm{~cm}$ total length, Persson, 1983), ruffe and gudgeon. The maximum relative species frequency was $14.2 \%\left((3 / 21)^{*} 100\right)$. This value was taken as the GEP status. The metric was depth-dependent.

- Number of piscivorous species (MnsPis) (fyke data)

Five species were assessed: burbot, wels catfish (Silurus glanis, LINNAEUS, 1758), pikeperch, perch $(\geq 13 \mathrm{~cm}$ total length, KOTTELAT \& FREYHOF, 2007) and pike. MEP status was obtained when five piscivorous species were caught. For the GEP status three of these species were needed (60\%). Indeed, according to the WFD, GEP tallies with slight changes in the values of the relevant biological quality elements as compared to the values found at maximum ecological potential (EU WATER FRAMEWORK DIRECTIVE, 2000). This metric was independent from depth and surface. 
TABLE 2

Reaction of metrics with uncorrelated pressures in reservoirs. The linear mixed model (lmer) assessed how far uncorrelated descriptors and pressures scores (Surlake: reservoir surface; Depth: average depth of reservoir; Dev: percentage of construction; Agr: percentage of agriculture activities; Tree: percentage of trees: Nat: percentage of natural banks) described metrics (log $(\mathrm{L})$ or square root $(\mathrm{SR})$ transformed (metric abbreviations are explained in Table 1).

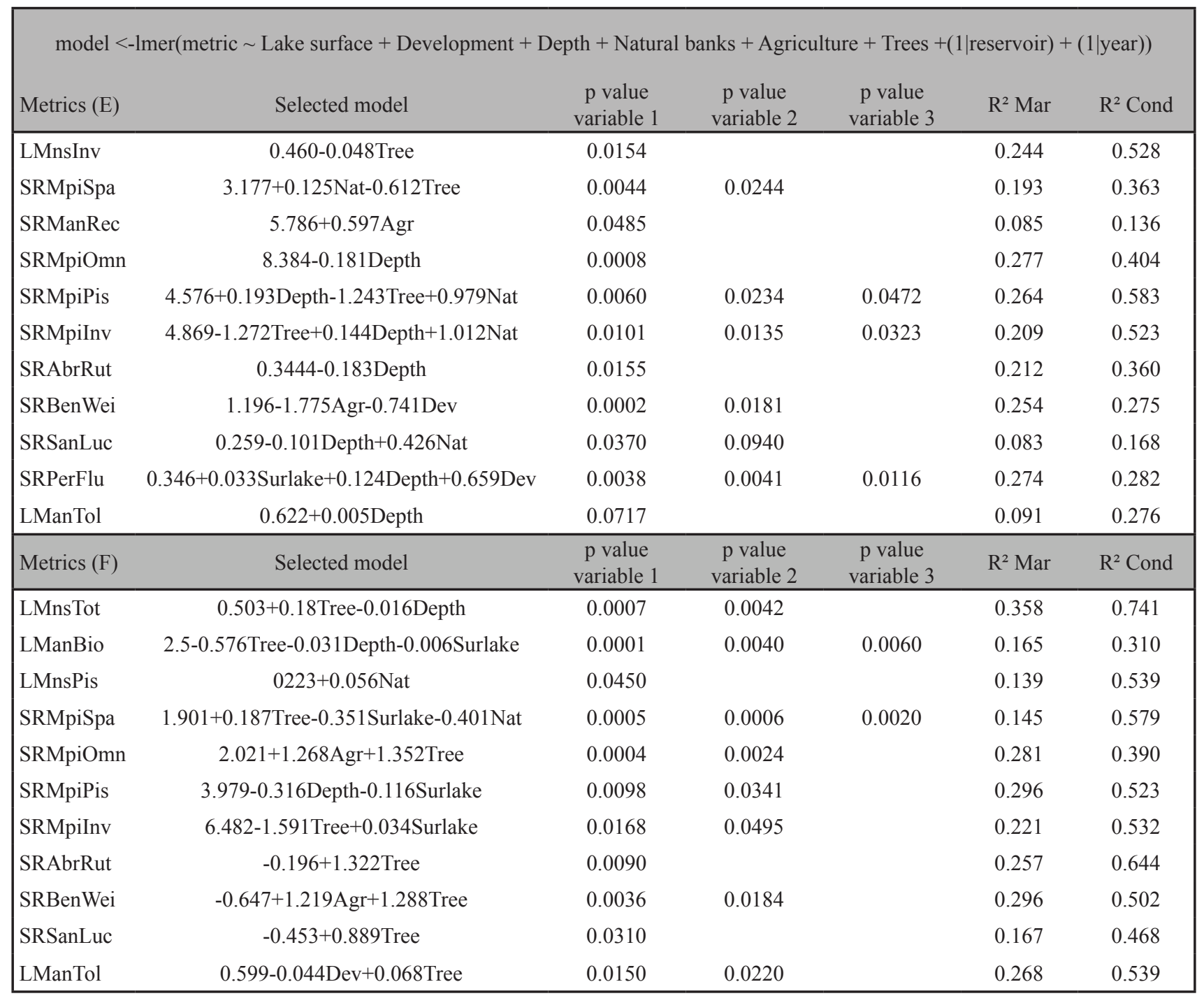

- Percentage of omnivorous individuals (MpiOmn) (fyke nets)

The omnivorous species included three-spined stickleback (Gasterosteus aculeatus, Linnaeus, 1758), eel, tench, bream, Prussian carp, common carp, ide (Leuciscus idus, Linnaeus, 1758), ninespine stickleback (Pungitius pungitius, Linnaeus, 1758), roach and rudd. The maximum relative species frequency was $47.6 \%$ $\left((10 / 21)^{*} 100\right)$, which was taken as the threshold between bad and poor status. A minimum weight percentage $(7.9 \%)$ was defined by expert judgment whereby the MEP/GEP threshold $(15.9 \%)$ was divided by two. This metric was independent from depth and surface.

- Benthivore species (BenWei, \% relative weight) (fyke nets)

The benthivorous species considered were bream, white bream (Blicca bjoerkna, Linnaeus, 1758), common carp, ruffe and tench. The average value for all surveys ( $\mathrm{n}=197)$ was $18.1 \%$ and the average value for sites in a poor status was $42.0 \%$ representing the threshold between 
bad and poor. A minimum weight percentage (7\%) was defined as a minimum of benthivores that should be present, whereby the MEP/GEP threshold (14\%) was divided by two. This metric was independent from depth and surface.

- Tolerance value (ManTol) (fyke nets)

If all reference species are present in one reservoir, then the maximal tolerance value of 50 was obtained, which is the sum of all tolerance values. The GEP status was obtained when 17 species were present $(80 \%)$. The tolerance value of the 17 most frequently caught species was 40. This value was taken as the lower threshold for the GEP status. This metric was independent from depth and surface.

\section{- Index scoring: EQR}

Within one reservoir, data from different surveys within one year were grouped per method, giving one index value for each method. The sum of the metric scores obtained with each method gave the IBI score for a particular site. The maximum sum of the IBI scores is 5.2 as only two metrics have a MEP threshold value. The minimum possible sum of the IBI scores is $1.2(6 * 0.2)$. This score was transformed to an EQR calculated as a value between 0 and 1 . The appreciation of the status was defined by the EQR value (see Table 4).

Internal validation was performed using data of 17 reservoirs. We calculated the final EQR
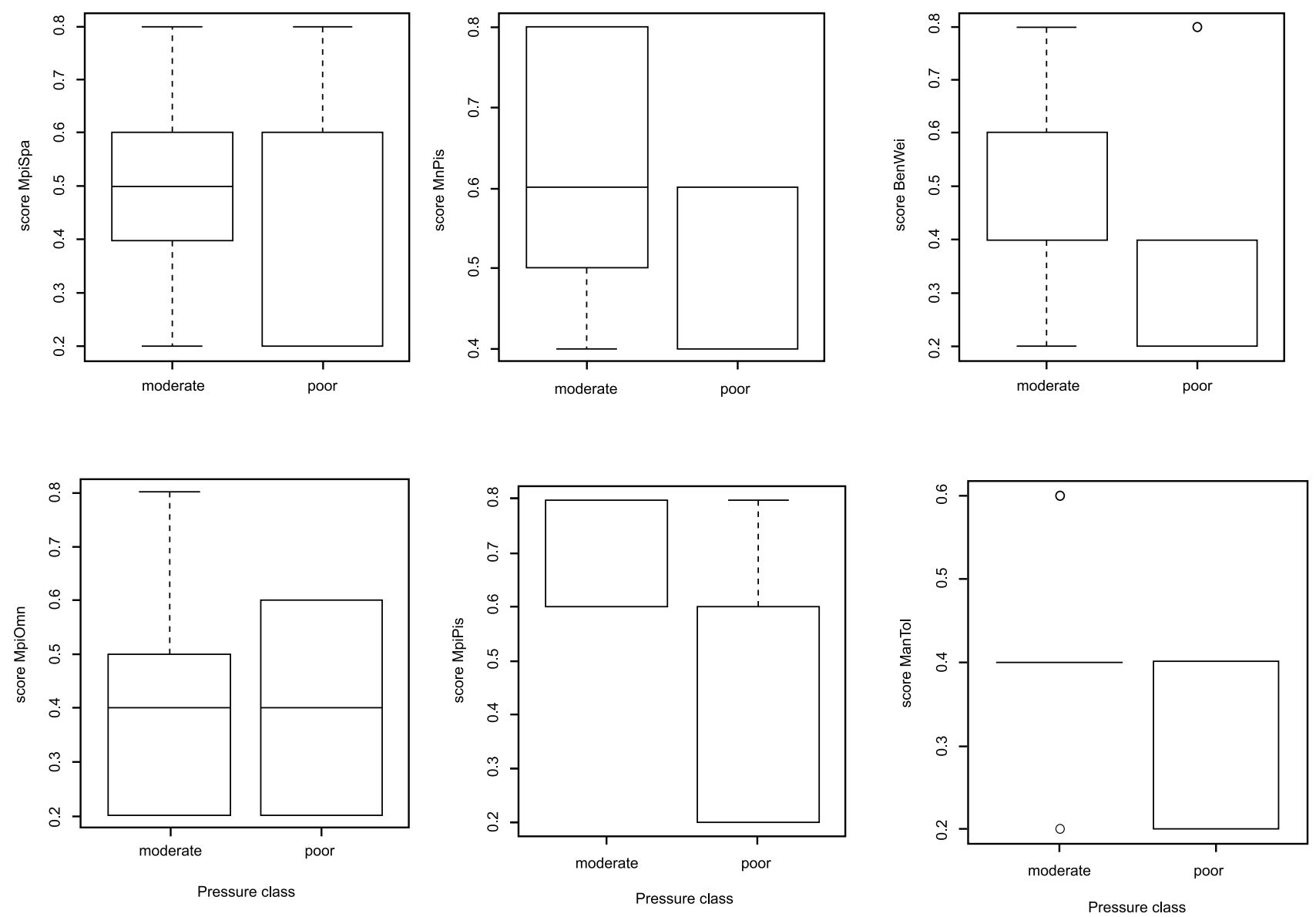

Fig. 2 - Graphical screening of the scores of selected metrics as a function of the pre-classification of the reservoirs (Pressure class) by boxplots (for abbreviation of the metrics, see Table 1); bolt line = median, hinges $=25^{\text {th }}$ and $75^{\text {th }}$ percentiles, whiskers $=$ range. 
TABLE 3

Pearson coefficient (c) and significance $(* * p \leq 0.001 ; * \mathrm{p} \leq 0.05)$ for correlation analysis of model fitted metrics with electric and fyke data (abbreviations, see Table 1).

\begin{tabular}{|c|c|c|c|c|c|c|c|c|c|c|}
\hline Electric & MnsInv & MpiSpa & ManRec & MpiOmn & MpiPis & MpiInv & AbrRut & BenWei & PerFlu & SanLuc \\
\hline MpiSpa & 0.0481 & 1 & & & & & & & & \\
\hline ManRec & 0.0965 & $0.2788^{*}$ & 1 & & & & & & & \\
\hline MpiOmn & -0.1699 & $0.0205^{*}$ & $-0.1964 *$ & 1 & & & & & & \\
\hline MpiPis & $0.2766^{*}$ & $0.2166^{*}$ & $0.1864 *$ & $-0.7123 * *$ & 1 & & & & & \\
\hline MpiInv & $0.3700^{* *}$ & 0.1153 & $0.2349 *$ & $-0.7051 * *$ & $0.9266^{* *}$ & 1 & & & & \\
\hline AbrRut & 0.0334 & $-0.2274 *$ & $0.2003 *$ & $0.2955^{*}$ & $-0.1937^{*}$ & -0.0756 & 1 & & & \\
\hline BenWei & 0.1654 & 0.2111 & 0.1412 & 0.0456 & -0.1139 & -0.0401 & 0.018 & 1 & & \\
\hline PerFlu & 0.1182 & -0.0756 & $0.2642 *$ & $-0.5314 * *$ & $0.6938 * *$ & $0.6993^{* *}$ & 0.0561 & $-0.2327^{*}$ & 1 & \\
\hline SanLuc & 0.1363 & -0.0243 & $-0.1897 *$ & 0.0976 & -0.0158 & -0.0602 & -0.0003 & -0.0673 & $-0.2387^{*}$ & 1 \\
\hline ManTol & 0.1330 & $0.4280 *$ & -0.0267 & -0.0716 & $0.1904 *$ & 0.0941 & $-0.2247^{*}$ & 0.0290 & 0.03782 & $-0.3105^{*}$ \\
\hline Fykes & MnsTot & ManBio & MnsPis & MpiSpa & MpiOmn & MpiPis & MpiInv & AbrRut & BenWei & SanLuc \\
\hline ManBio & $0.8138^{* *}$ & 1 & & & & & & & & \\
\hline MnsPis & $0.5750 * *$ & $0.4796^{* *}$ & 1 & & & & & & & \\
\hline MpiSpa & $0.2657 * *$ & $0.1303^{*}$ & -0.0404 & 1 & & & & & & \\
\hline MpiOmn & $0.4891 * *$ & $0.6088^{* *}$ & 0.1635 & $0.2625 * *$ & 1 & & & & & \\
\hline MpiPis & $-0.2866^{* *}$ & $-0.2991 * *$ & $0.5132 * *$ & $-0.3236^{* *}$ & $-0.5729 * *$ & 1 & & & & \\
\hline MpiInv & 0.0878 & 0.0391 & $0.3967 * *$ & $-0.1591 *$ & $-0.2003 *$ & $0.5904 * *$ & 1 & & & \\
\hline AbrRut & $0.5928 * *$ & $0.3390^{*}$ & $0.2711^{* *}$ & 0.0900 & $0.3486^{* *}$ & $-0.1780 *$ & -0.0672 & 1 & & \\
\hline BenWei & $0.5391 * *$ & $0.4457^{* *}$ & 0.1795 & $0.1892 *$ & $0.4060 * *$ & $-0.3292 * *$ & -0.1071 & $0.4883^{* *}$ & 1 & \\
\hline SanLuc & $0.2201 * *$ & $0.1935^{*}$ & $0.3908 * *$ & $-0.1974 *$ & -0.0400 & $0.2814 * *$ & $-0.2182 *$ & 0.1029 & 0.0575 & 1 \\
\hline ManTol & $0.3506^{* *}$ & $0.4505^{* *}$ & $0.3795^{* *}$ & $0.2322 *$ & $0.4002 * *$ & $0.1821^{*}$ & $0.5469 * *$ & 0.0405 & 0.1603 & $-0.1484^{*}$ \\
\hline
\end{tabular}

and compared its appreciation (i.e. integrity class) with the pressure status. One reservoir reached the GEP status, one had a bad status, six obtained a poor status, and nine had a moderate status (Table 5). Thirteen reservoirs had the same EQR appreciation as the pressure status (pressure class). Three reservoirs scored too high, i.e. the EQR was higher than the pressure status (one class difference). One reservoir scored too low two class differences).

For the external validation of the EQR of nine reservoirs (independent data), a high correspondence was found between the EQR appreciation and the attributed pressure status. Only one reservoir scored differently.

The Pearson correlation between the averaged EQR values $(n=26)$ obtained with the initial index from BELPAIRE et al. (2000) and the new EQR values did not show a significant correlation $(\mathrm{c}=0.108 ; \mathrm{p}=0.598)$. With the old index, 14 reservoirs obtained an ecological status that diverged one class from the pressure status, and one reservoir diverged two classes (Table 5). The new index assessed the same reservoirs more accurately: only five showed a difference of one class. The new index also seemed to better separate the different pressure classes (Fig. 3).

\section{DISCUSSION}

\section{Reference list}

Species in the reference list are similar to those described for the Netherlands (BACKX et al., 2008). However, we did not include the European weatherfish (Misgurnus fossilis LINNAEUS, 1758) and spined loach (Cobitis 
TABLE 4

Selected metrics for reservoirs and their threshold values for the metric and EQR-scores (abbreviations, see Table 1).

\begin{tabular}{|lccccc|}
\hline & MEP & GEP & Moderate & Poor & Bad \\
\hline metric - score & 1 & 0.8 & Electric data & 0.4 & 0.2 \\
MpiSpa (\%) & & $<28.5 \geq 21.4$ & $\geq 28.5 \&<21.4 \geq 14.2$ & $<14.2 \geq 7.1$ & $<7.1$ \\
MpiInv (\%) & & $<28.9 \geq 14.2$ & $\geq 28.9 \&<14.2 \geq 9.4$ & $<9.4 \geq 4.7$ & $<4.7$ \\
& & \multicolumn{4}{c}{ Fyke net data } \\
metric - score & 1 & 0.8 & 0.6 & 0.4 & 0.2 \\
MpiOmn (\%) & & $<15.9 \geq 7.9$ & $<31.7 \geq 15.9 \&<7.9$ & $<47.6 \geq 31.7$ & $\geq 47.6$ \\
MnsPis (\#) & 5 & $<5 \geq 3$ & 2 & 1 & 0 \\
BenWei (\% weight) & & $<14 \geq 7$ & $<28.0 \geq 14.0 \&<7$ & $<42.0 \geq 28.0$ & $\geq 42.0$ \\
ManTol & 50 & $<50 \geq 40$ & $<40 \geq 27$ & $<27 \geq 13$ & $<13$ \\
EQR & 1 & $<1 \geq 0.75$ & $<0.75 \geq 0.50$ & $<0.50 \geq 0.25$ & $<0.25$ \\
Appreciation & MEP & GEP & Moderate & Poor & Bad \\
\hline
\end{tabular}

taenia LINNAEUS, 1758) as these do not (or rarely) occur in our reservoirs. Rheophilic species were omitted as they do not occur naturally in standing waters. We did not include alien species in our list. Unlike the observations by VANDEKERKHOVE et al. (2013), their presence was not always an indication of malfunctioning of the ecosystem as some of our alien species have relative high quality demands. In addition, some alien species only reside for a short time; e.g. the brown bullhead (Ameiurus nebulosus LESUEUR, 1819) is disappearing from Flemish reservoirs (Schulensmeer, authors' observations between 1998-2011). Other species remaining for decades in our waters, e.g. pike-perch, are considered as naturalised. Only species occurring in the reference list were considered to assess the ecological quality of the reservoir. This approach is similar to the one used in BREINE et al. (2010).
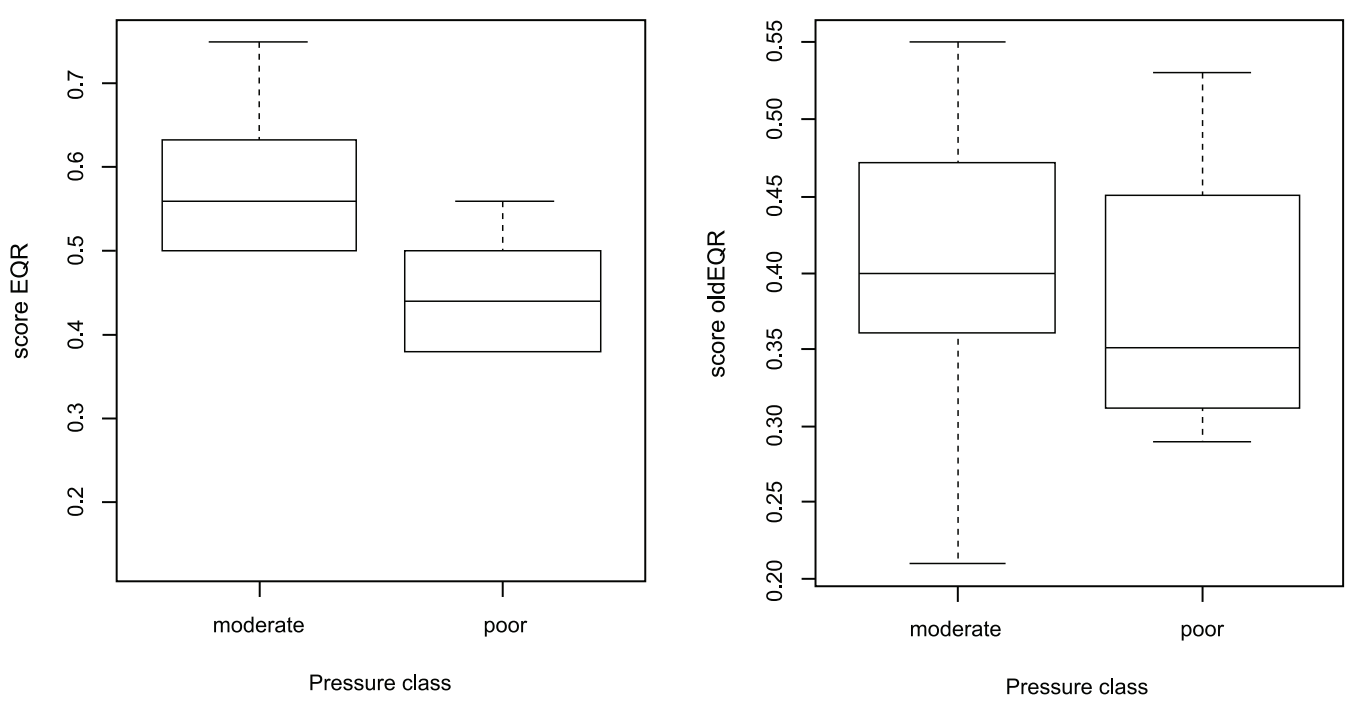

Fig. 3 - Boxplots showing the EQR value variation of the new and old index in the different pressure classes; bolt line $=$ median, hinges $=25^{\text {th }}$ and $75^{\text {th }}$ percentiles, whiskers $=$ range. 


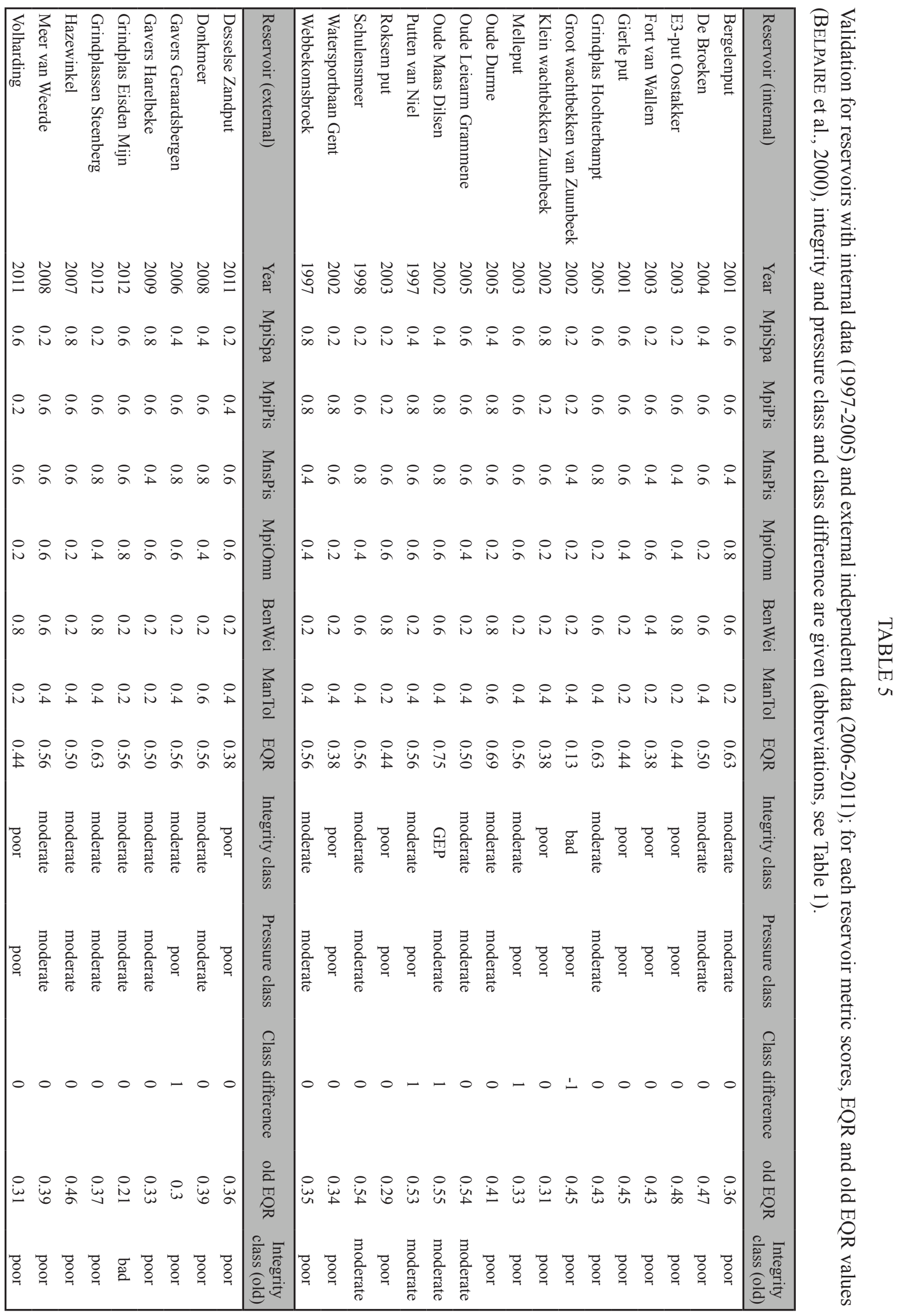




\section{Pre-classification}

Similar to the approach explained by BREINE et al. $(2007,2010)$ and QUATAERT et al. (2011), the pre-classification is a device to rank reservoirs in a reasonable way with respect to anthropogenic pressures enabling the construction of a biotic index. The thresholds for the pre-classification attribution were based on expert judgement. However, the main point was not to have an absolute expression of the quality, but to have a good ranking with respect to human impact. The pre-classification of reservoirs based on abiotic variables is an important issue. It was used to make a first selection among the candidate metrics and for the external validation. The combination of scores expressing the pressures classified the reservoirs. Land cover percentages were also used by DRAKE \& PEREIRA (2002). One of the largest factors contributing to impairment, namely non-point source pollution, is commonly associated with land-use modification (e.g., agriculture, urbanization) leading to eutrophication of surface waters (WANG et al., 2001; DoDDs et al., 2009). As we focused on direct impacts from the neighbourhood, a zone of $100 \mathrm{~m}$ surrounding the reservoir was appropriate. Pre-classifying the reservoirs with presence absence data only ( 0 or 1 ) reduced the ranking efficiency as all reservoirs got the same score. Modelling with raw pressure values (log transformed) did not provide better results. Only for electric data, two metrics produced significant results: the metric 'relative percentage weight of perch' (PerFlu 0,7563+0,0314Surlake $+0,118$ 2 Depth $+0,0459$ Dev, $R^{2}$ conditional $=0.253$ ) and 'the relative percentage weight of pike-perch' (SanLuc 1,9371+0,064Agr, $\mathrm{R}^{2}=0.294$ ). Fyke data did not produce significant results.

We acknowledge that some important parameters were missing in our assessment, e.g. total phosphorus and total nitrogen (LAUNOIS et al., 2011b). Total phosphorus is an important parameter to assess the eutrophication of lakes and reservoirs (WETZEL, 1983). Nitrogen increases with human activities but is too variable to be a robust parameter (Moss et al.,
2003). We used agricultural activity as a proxy for these parameters as measurements were only made in some reservoirs. The selected pressure parameters are known to have a negative impact on fish assemblages (DRAKE \& PEREIRA, 2002; BACKX et al., 2008; LAUNOIS et al., 2011b, ARGILLIER et al., 2013).

\section{Fishing methods}

A single method underestimates the species richness (JACKSON \& HARVEY, 1997). For lakes and reservoirs no single type of fishing gear is sufficient to survey all habitat types or to sample all fish species (WHITTIER, 1999; BONAR et al., 2009; KUBEČKA et al., 2009). The need to use multiple types of gear is a result of habitat heterogeneity, and the differences in habitat use of the associated species in lakes and reservoirs (FISCHER, 2012). In lakes and reservoirs fish can be pelagic, demersal or benthic. Therefore, adapted techniques should be used to assess the presence of the fish occurring in the water column or dwelling near the bottom. In deep reservoirs or lakes, electric fishing cannot be used nor can fykes easily be placed in vegetated habitats. As a consequence, data collected with multiple methods allows greater reliability in interpretations using information on lentic fish assemblages. By using different methods, we can retrieve a more accurate picture of the fish assemblage and therefore the ecological status of a reservoir (or lake) can be more precisely assessed. Multi-mesh gillnets are not used in Flanders as this method results in high fish mortality. Electric fishing in the littoral zone and fyke nets on the bottom are effective for sampling in lakes (JENnINGS et al., 1999). The sampling effort for each method should be such that adding an additional unit effort should not substantially increase species number or change proportional abundances. The fish protocol currently used in reservoirs in Flanders (1 fyke/ha overnight for two successive days with a minimum of 4 and a maximum of 20 per reservoir combined with electric fishing along $250 \mathrm{~m}$ long shore transects 
per ha) has proven to fulfil this requirement (see also BELPAIRE et al., 2000).

\section{Metric selection}

The list of candidate metrics was based on literature. These metrics were chosen for their known reaction to human induced pressures and because they assess complementary aspects of the ecological functioning of the lakes. No explicit metric assessing alien species was included. The rationale is that if there is a significant pressure by alien species, this will be detected by other metrics.

The modelling approach allowed a first selection of metrics based on their sensitivity for one or more pressures. Only species occurring in the reference lists were considered for the calculation of the metric value. If only one fishing method had been used, the index would have consisted of less metrics. As a consequence, some effects of human disturbance would not have been assessed. Here, electric data metrics were sensitive to changes of the banks, while fyke net metrics also assessed impacts from agriculture and development. Our models showed that habitat quality (natural state of bank) and agricultural activities were major pressures explaining changes in fish assemblages. This corresponds with observations by LAUNOIS et al. (2011b) where habitat alterations and eutrophication in lakes seem to have a prominent effect on fish assemblages. European fish-based indices for lakes assess primarily eutrophication (RITTERBUSCH et al., 2011). To avoid over-fitting, a Pearson correlation was applied for examining redundancy among metrics. This method has also been applied by other authors (e.g. MinNs et al., 1994; MCCORMICK et al., 2001). Graphical screening of the selected metrics as a function of the pre-classification of the reservoirs by boxplots also showed that for nearly all metrics a clear gradient was seen (Fig. 2). The metric 'percentage of omnivores' was retained, though it did not seem to separate the pressure classes well. We considered that a less optimal metric can sometimes give invaluable information in combination with other metrics (BREINE et al., 2007).

\section{Rejected metrics fitted by the model}

For electric fishing, the metrics assessing the 'invertivorous species' (MnsInv), 'percentage of omnivores' (MpiOmn), the 'relative combined weight of bream and roach' (AbrRut) and the 'tolerance values' (ManTol) were rejected as they only reacted to descriptors (deforestation or depth, Table 2). $\mathrm{R}^{2}$ for the metric 'percentage of species that recruit' (ManRec) was small and its reaction to pressure was opposite to what was expected. Metrics assessing the 'relative percentage weight of perch' (PerFlu), 'benthivore species' (BenWei) and 'percentage weight of pike-perch' (SanLuc) were fitted but did not show the expected response.

For metrics assessing fyke net data, we rejected all metrics reacting to descriptors only. These included 'total number of species' (MnsTot), 'total biomass' (ManBio), 'percentage of piscivores' (MpiPis) and 'invertivores' (MpiInv), the 'relative combined weight of bream' (AbrRut) and the 'percentage weight of pike-perch' (SanLuc). The metric 'specialised spawners' (MpiSpa) was not selected as it decreased with increasing habitat quality, which was rather unexpected.

\section{Properties of the selected metrics}

- Percentage specialised spawners (MpiSpa) (electric data)

This metric was previously proposed by DIDIER (1997) and BREINE et al. (2004). It includes species having specific demands for spawning, and nest builders. As such, it assesses degradation of the spawning habitat. Due to degradation, fish will not spawn successfully and this will be reflected by the absence of one or more year classes or eventually lead to the extinction of one or more species (NICOLA et al., 1996; GASSNER et al., 2003). Extremely high values indicate a 
disturbance (moderate status). In our study this metric reacted to the natural state of the banks. This metric scored $61.1 \%$ of the reservoirs in agreement with the pre-classification (Fig. 2).

- Percentage of invertivorous individuals (MpiInv) (electric data)

This metric is often integrated in an IBI (HUGHES \& OBERDORFF, 1999). The invertivorous level decreases with degradation (BELPAIRE et al., 2000). In French lakes, this metric did not show a response with pressure because the assessed species were overall tolerant to degraded lake conditions (LAUNOIS et al. ,2011b). Here, we did not consider overall tolerant species, i.e. perch $(<13 \mathrm{~cm})$, ruffe and gudgeon. In our study this metric reacted to the natural state of the banks. Here, $83.3 \%$ of the reservoirs were correctly scored (Fig. 2).

- Number of piscivorous species (MnsPis) (fyke data)

The top of the food chain is represented by predators. This constitutes the piscivorous level, which also is sensitive to degradation (SHIELDS et al., 1995; MiLler et al., 1988; STEEDMAN, 1988). The presence of trophic specialists is very sensitive to increasing pressure and is often integrated in an IBI (HUGHES \& OBERDORFF, 1999). This metric decreases in value as human impact increases (BACKX et al., 2008; BELPAIRE et al., 2000; LAUNOIS et al., 2011a). With our data this metric was sensitive to changes in habitat. A total of $55.5 \%$ of reservoirs were scored correctly using this metric.

- Benthivore species (BenWei, \% weight) (fyke nets)

High values of the metric indicate unspecific degradation including eutrophication (RITTERBUSCH et al., 2011). It measures the abundance of littoral and some pelagic species. Benthivore species are also used in the assessment systems of Germany, Lithuania, The Netherlands and Poland (RITTERBUSCH et al., 2011). In our study, the metric reacted to agricultural activities and scored $83.3 \%$ of the reservoirs correctly.
- Percentage of omnivorous individuals (MpiOmn) (fyke nets)

Increasing abundances of omnivores are observed in eutrophic, constructionally-modified lakes; and with increasing pressures (HICKMAN \& MCDONOUGH 1996; WhitTIER 1999; DRAKE \& PEREIRA, 2002). As eutrophication increases, the consequent higher primary production will lead to a higher total fish biomass (BELPAIRE et al., 2000). The absence of chemical pollution in Flemish reservoirs can explain why, in our study the metric is not bi-directional. The metric reacted to agricultural activities. Only $44.4 \%$ of the reservoirs were correctly classified.

\section{- Tolerance value (ManTol) (fyke nets)}

It is a good indication of human impact as lower values correspond with higher habitat degradation. The metric was selected as it reacts to construction. Using this metric $61.1 \%$ of the reservoirs were scored correctly. The mean tolerance value was also used in BELPAIRE et al. (2000) to assess the quality of standing waters in Flanders. It has also been used to assess ecosystem conditions in the US (NOVOTNY et al., 2005; MEADOR \& CARLISE, 2007).

\section{Metric scoring}

Four metrics contain species that were rarely (crucian Carp (Carassius carassius Linnaeus, 1758), gudgeon, ide and ninespine stickleback) or never (burbot and wels catfish) caught. These species were still included as they are not extirpated, and because lakes or reservoirs are their preferred habitat. Including these species in the assessment did not affect the attribution of thresholds for the metric scores because $60 \%$, for metrics assessing number of species, was taken as GEP. To compensate for gear specificity, the threshold values for metric 'tolerance value' were defined using the 17 most frequently caught species $(80 \%)$. For the 'number of piscivorous species', three out of five species was scored as 'good'. Thresholds for the 'relative percentage of specialised spawners' and 'piscivores' were based on the 
reference list independently from the catch results. Boxplots showed that, although overlaps exists, these metrics efficiently separated the different pressure classes. No adjustment for surface or depth was needed for the selected metrics (Table 2). Only MpiInv (electric fishing, Table 2) seemed to be influenced by depth, but in the model it had a small coefficient and scores were therefore attributed independently of the depth. Several methodologies were applied to determine metric scoring criteria whereby reference sites play a major role (BECK \& $\mathrm{HATCH}$, 2009). In the absence of reference conditions, minimally disturbed sites are sometimes used to select optimal metric scores and score classes are determined by dividing the total metric range into three or five equal portions (assuming a linear behaviour of the metrics) (BREINE et al., 2010). The Dutch fish-based index for lakes also uses the developed reference as a benchmark for the metric scoring (BACKX et al., 2008). Other member states use type-specific near reference sites to score the selected metrics (e.g. BELPAIRE et al, 2000; GASSNER et al., 2003; LAUNOIS et al., 2011a). Adapting this species list was the best option as the reservoirs in this study are impacted (moderate in the best case). Dividing the metric values into equal parts is a widely applied approach for indices (GofFAUX et al., 2001). Due to data limitation, no other approach (linear regression or modelling) could be applied here to define metric thresholds. Only on two occasions was expert judgment used to define threshold values between the poor and bad status. For the 'percentage of omnivorous individuals' (MpiOmn) expert judgement (dividing MEP/ GEP threshold) was used only to define the minimum weight. A similar approach indicated the minimum weight for the metric assessing the 'benthivore species' (BenWei, \% relative weight). The importance of this threshold is much less than the boundary between good and moderate. Indeed, according to the WFD, no actions have to be undertaken when a good status is reached. In a lower status (moderate, poor and bad) however, actions to improve the ecological status are needed.

\section{The index score}

In our study, data from different methodologies was assessed with different metrics as suggested by JENNINGS et al. (1999) and BECK \& HATCH (2009). The index score was obtained by the sum of the individual gear-specific metrics. This value was then transformed to an EQR and an appreciation was attributed. Integrity classes have equal distance intervals. To define tendencies, of under- or over-estimation, we allowed a one-class difference between the habitat status (pre-classification) and the EQR as was done by GOFFAUX et al. (2001) and BREINE et al. (2004, 2011). Our validation showed that the newlydeveloped index was able to distinguish between different degrees of degradation within the preclassified reservoirs. We consider the new index as an improvement as the EQR corresponded generally better with the attributed pressure status compared to the old index (Fig. 3). The first index for standing waters in Flanders (BELPAIRE et al., 2000) assessed reservoirs by combining fish results obtained from different fishing strategies without considering the gear specificity of these methods. In addition, the approach used now seems to be more robust as less expert judgement was used.

\section{CONCLUSIONS}

We developed a multi-metric index for reservoirs taking into consideration the different standardised sampling methodologies. The main aim was to present an approach that could be applied with any given set of data. The selected metrics are relevant allowing for an appropriate assessment of anthropogenic impacts on the fish communities. We also ensured that the metrics assess different aspects of the ecological functions of reservoirs for fishes, and that they are not redundant. The reference list provides a realistic goal i.e. presence of reference species corresponds to a good ecological potential. Finally the index is a clear communication tool for environmental managers, politicians and other target groups. 


\section{ACKNOWLEDGEMENTS}

We are grateful to Dr Ritterbusch for valuable information and guidelines. We appreciate the comments and improvements of H. Verreycken and three anonymous referees. A. De Bruyn and L. Galle assisted in the quest for abiotic data and in the field. Thanks are due to our technical staff for fishing in sometimes difficult conditions: D. Bombaerts, S. Buekenhout, J-P. Croonen, F. Dens, M. Dewit, J. Ghysels, J. Janssens, I. Lambeens, Y. Maes, J. Moysons, K. Perremans, A. Vanderkelen, T. Van Dessel and J. Van Overberghe. Finally, we thank T. De Boeck for his assistance with all databank issues.

\section{REFERENCES}

APPelberg M, Bergquist BC \& Degerman E (2000). Using fish to assess environmental disturbance of Swedish lakes and streams a preliminary approach. Verhandlungen der Internationalen Vereinigung für Limnologie, 27:311-315.

Argillier C, Caussé S, Gevrey M, Pédron M, DE BORTOLI J, BRUCET S, EMMRICH M, JEPPESEN E, LAURIDSEN T, MEHNER T, OLIN M, RASK M, Volta P, Winfield IJ, Kelly F, KRAUSE T, PALM A \& HolmGRen K (2013). Development of a fishbased index to assess the eutrophication status of European lakes. Hydrobiologia, 704 (1):193-211.

BACKX JJGM, BEERS M, Higler B, JAARSMA N, Klinge M, Kranenbarg J, De Leeuw J, OttBuRG F, VAN DE VEN M \& VRIESE T (2008). Achtergronddocument referenties en maatlatten vissen ten behoefte van de kaderrichtlijn water. 110 pp. (In Dutch)

BECK MW \& HATCH LK (2009). A review of research on the development of lake indices of biotic integrity. Environmental Reviews, 17:21-44.

Belpaire C, Smolders R, Vanden Auweele I, Ercken D, Breine J, Van Thuyne G \& OlLEVIER F (2000). An Index of Biotic Integrity characterizing fish populations and the ecological quality of Flandrian water bodies. Hydrobiologia, 434:17-33.

Bonar SA, Hubert W \& WiLlis D (2009). Standard methods for sampling North American freshwater fishes. American Fisheries Society, 335 pp.
Breine J, Maes J, Quataert P, Van den Bergh E, Simoens I, VAN Thuyne G \& Belpaire C (2007). A fish-based assessment tool for the ecological quality of the brackish Schelde estuary in Flanders (Belgium). Hydrobiologia, 575 (1):141-159.

Breine J, Quataert P, SteVens M, Ollevier F, Volckaert F, VAN DEN Bergh E \& MAes J (2010). A zone-specific fish-based index as a management tool for the Zeeschelde estuary (Belgium). Marine Pollution Bulletin, 60 (7): 1099-1112.

Breine J, Simoens I, Goethals P, Quataert P, ERCKEN D, VAN LIEFFERINGE $C$ \& Belpaire C (2004). A fish-based index of biotic integrity for upstream brooks in Flanders (Belgium). Hydrobiologia, 522:133-148.

Breine J, Simoens i, Haidvogl G, Melcher A, PONT D \& SCHMUTZ S (2005). Manual for the application of the European Fish Index - EFI. A fish-based method to assess the ecological status of European rivers in support of the water framework directive. Version 1.1, January 2005, $81 \mathrm{pp}$.

Breine J, Stevens M, Van den Bergh E \& Maes J (2011). A reference list of fish species for a heavily modified transitional water:The Zeeschelde (Belgium). Belgian Journal of Zoology, 141 (1):44-55.

Carol J, Benejam L, Alcaraz C, Vila-Gispert A, ZAMORA L, NaVArro E, ARMENGol J \& GARCIA-BERTHOU E (2006). The effects of limnological features on fish assemblages of 14 Spanish reservoirs. Ecology of Freshwater Fish, 15 (1):66-77.

CASSELMAN JM \& HARVEY HH (1975). Selective fish mortality resulting from low winter oxygen. Verhandlungen der Internationalen Vereinigung für Limnologie, 19:2418-2429. (in German)

Catalan J \& Ventura M (2003). Desenvolupament d'un índex integral de qualitat ecològica $\mathrm{i}$ regionalització ambiental dels sistemes lacustres de Catalunya. Centre d'Estudis A-vançats (CSIC), Agència Catalana de 1'Aigua, Generalitat de Catalunya, Departament de Medi Ambient i Habitatge, Blanes, 177 pp. (in Catalan)

CEN (2005). Water quality - sampling of fish with multi-mesh gillnets 08/2005. EN 14757.

Chow-Fraser P, Kostuk K, Seilheimer T, WEIMER M, MACDOUGALL $T$ \& THEŸSMEŸER $\mathrm{T}$ (2006). Effect of wetland quality on sampling bias associated with two fish survey methods 
for coastal wetlands of the lower Great Lakes. In:SIMON TP \& STEWART PM (eds), Coastal wetlands of the Laurentian Great Lakes:health, habitat and indicators, Indiana Biological Survey, Bloomington, Indiana:239-262.

CWD (2012). Report of the commission to the European Parliament and the Council on the Implementation of the Water Framework Directive (2000/60/EC); Commission Staff Working Document, Brussels, 139 pp.

DIDIER J (1997). Indice biotique d'intégrité piscicole pour évaluer la qualité écologique des écosystèmes lotiques. Thèse de doctorat Presses Universitaires de Namur, Namur, 273 pp. DodDS WK., BoUSKA W, Eitzmann JL, Pilger TJ, PitTs KL, Riley AJ, SChloesser JT \& DJ Thonbrugh (2009). Eutrophication of U.S. freshwaters:analysis of potential economic damages. Environmental Science and Technology, 43 (1):12-19.

Drake MT \& Pereira DL (2002) Development of a fish-based index of biotic integrity for small inland lakes in Central Minnesota. North American Journal of Fisheries Management, 22 (4):1105-1123.

EMMrich M, BRUCET S, RitTerbusch D \& MEHNER T (2011). Size spectra of lake fish assemblages:responses along gradients of general environmental factors and intensity of lake-use. Freshwater Biology, 56 (11):2316-2333.

EU Water Framework Directive (2000). Directive of the European parliament and of the council 2000/60/EC establishing a framework for community action in the field of water policy. Official Journal of the European Communities 22.12.2000 L 327/1.

FAO (1984). Inland Aquatic Engineering. Project Reports ADCP/REP/21, 596 pp.

FAO (1989). Selected aspects of warmwater fish culture. A compilation based on lectures presented at a series of FAO/AGFUND International Training Courses in Aquaculture hosted by Hungary in 1987 and 1988. GCP/INT/435/AGF, $181 \mathrm{pp}$.

FisHeR JR (2012). Characterizing lentic fish assemblages and community-environment relationships:An evaluation of natural lakes and reservoirs in Iowa, USA. Graduate Theses and Dissertations. Paper 12854 Iowa State University, $133 \mathrm{pp}$.

Garcia X-F, DieKMANn M, BRÄMick U, LEMCKe R $\&$ MEHNER T (2006). Correlations between type indicator fish species and lake productivity in German lowland lakes. Journal of Fish Biology, 68 (4):1144-1157.

GASSNER H, TISChLER G \& WANZENBÖCK J (2003). Ecological integrity assessment of lakes using fish communities - Suggestions of new metrics developed in two Austrian prealpine lakes. International Review of Hydrobiology, 88 (6):635-652.

Goffaux D, Roset N, Breine JJ, De Leeuw JJ, OBERDORFF T \& KESTEMONT P (2001). A biotic index of fish integrity (IBIP) to evaluate the ecological quality of lotic ecosystems - application to the Meuse River basin. Final Report:Life97/ ENV/B/000419:171 pp.

HICKMAN GD \& MCDONOUGH TA (1996). Assessing the reservoir fish assemblage index:A potential measure of reservoir quality. In:MIRANDA LE \& DE VRIES DR (eds), Multidimensional approaches to reservoir fisheries management, vol. 16. Chattanooga, Tennessee:American Fisheries Society, Bethesda, Mayrland, USA:85-97.

HOLMGREN K, KINNERBÄCK A, PAKKASMAA S, Bergquist B \& BeIER U (2007). Bedömningsgrunder för fiskfaunans status I sjoär. Fiskeriverket Informerar 3:54. (In Swedish)

HugHeS RM \& OBERDORFF T (1999). Applications of IBI Concepts and Metrics to Water Outside the United States and Canada. In: SIMON TP (ed), Assessing the Sustainability and Biological Integrity of Water Resources Using Fish Communities. CRC Press LLC, Washington DC:62-74.

JAARSMA N (2007). Description of references and metrics for fish in lakes in the Netherlands (unpublished). Witteveen \& Bos consulting engineers.

JACKSON DA \& HARVEY HH (1997). Qualitative and quantitative sampling of lake fish communities. Canadian Journal of Fisheries and Aquatic Sciences, 54:2807-2813.

JeNNINGS MJ, LyONS J, EMMONS EE, HATZENBELER GR, BOZEK MA, SIMONSON TD, BEARD JR. TD \& FAGO D (1999). Toward the development of an index of biotic integrity for inland lakes in Wisconsin. In:SIMON TP (ed), Assessing the Sustainability and Biological Integrity of Water Resources Using Fish Communities, CRC Press LLC, Washington DC:541-562.

JEPPESEN E, JENSEN JP, SøNDERgaARD M, LAURIDSEN T \& LANDKILDEHUS F (2000). Trophic 
structure, species richness, and biodiversity in Danish lakes:changes along phosphorus gradient. Freshwater Biology, 45:201-218.

JePPESEN E, MEHNER T, Winfield IJ, KANGUR K, SARVALA J, GERDEAUX D, RASK M, MALMQUist HJ, HOLMGREN K, VOlTA P, ROMO S, ECKMANN R, SANDSTRÖM A, BLANCO S, KANGUR A, RAGNARSSON STABO H, TARVAINEN M, VENTELÄ A-M, SøndergaArd M, LaURidSEn TL \& MEERHOFF M (2012). Impacts of climate warming on the long-term dynamics of key fish species in 24 European lakes. Hydrobiologia, 694:1-39.

KARR JR (1981). Assessment of biotic integrity using fish communities. Fisheries, 6 (6):21-27.

KARR JR, FAUSCH KD, ANGERMEIER PR, YANT PR \& SCHLOSSER IJ (1986). Assessing Biological Integrity in Running Waters:A Method and its Rationale. Illinois Natural History Survey Special Publication, 5:1-28.

KREBS CJ (1998). Ecological methodology, second edition. Benjamin Cummings, Menlo Park, California, $624 \mathrm{pp}$.

Kottelat M \& FreyHofF J (2007). Handbook of European freshwater fishes. Ch-2952 Cornol, 646 pp.

KubečKa J, Hohausová E, Matěna J, Peterka J, AMARASINGHE US, BonAR SA, HATELEY J, Hickley P, SUURONEN P, TERESCHENKo V, Welcomme R \& Winfield IJ (2009). The true picture of a lake or reservoir fish stock: A review of needs and progress. Fisheries Research, 96 (1):1-5.

LAunois L, Veslot J, IRZ P \& ARgillier C (2011a). Development of a fish-based index (FBI) of biotic integrity for French lakes using the hindcasting approach. Ecological Indicators, 11 (6):15721583 .

LAUNOIS L, Veslot J, IRZ P \& ARgillier C (2011b). Selecting fish-based metrics responding to human pressures in French natural lakes and reservoirs: towards the development of a fish-based index (FBI) for French lakes. Ecology of Freshwater Fish, 20 (1):120-132.

Lyche-Solheim A, Feld CK, Birk S, Phillips G, Carvalho L, Morabito G, Mischke U, Willby N, SøndergaARD M, HELlsten S, Kolada A, MJelde M, BöHMer J, Miler O, PUSCH MT, ARGILLIER C, JEPPESEN J, LAURIDSEN TL \& POIKANE S (2013). Ecological status assessment of European lakes: a comparison of metrics for phytoplankton, macrophytes, benthic invertebrates and fish. Hydrobiologia, 704 (1):5774.

MARSHALL TR (1977). Morphological, physiological, and ethological differences between Walleye (Stizostedion vitreum vitreum) and Pikeperch $(S$. lucioperca). Journal of Fisheries Board of Canada, 31(10):1515-1523.

LEWIS WM JR (1983). A revised classification of lakes based on mixing. Canadian Journal of Fisheries and Aquatic Sciences, 40 (10):1779-1787.

MCCORMick FH, Hughes RM, KaUfManN PR, Peck DV, Stoddard JL \& Herlihy AT (2001). Development of an index of biotic integrity for the Mid-Atlantic Highlands Region. Transactions of the American Fisheries Society, 130 (5):857877.

MEADOR MR \& CARLISE DM (2007). Quantifying tolerance indicator values for common stream fish species of the United States. Ecological Indicators, 7:329-338.

Mehner T, Diekmann M, Garcia X-F, Brämick U \& LEMCKE R (2004). Ökologische Bewertung von Seen anhand der Fischfauna. Berichte des IGB, 21:1-202.

Miller DL, LeONARd PM, Hughes RM, KarR JR, MOYLE PB, SCHRADER LH, THOMPSON BA, DANiels RA, FAush KD, Fitzhugh GA, GAMMON JR, HALliwel DB, ANGERMEIER PL \& ORTH DJ (1988). Regional applications of an index of biotic integrity for use in water resource management. Fisheries, 13 (5):12-20.

MinNS CK, CAIRnS VW, RANDALl RG \& MOORE JE (1994). An index of biotic integrity (IBI) for fish assemblages in the littoral zone of Great Lakes' areas of concern. Canadian Journal of Fisheries and Aquatic Science, 51 (8):1804-1822.

Moss B, Stephen D, Alvarez C, Becares E, Van De Bund W, Collings SE, Van Donk E, De Eyto E, Feldmann T, Fernandez-Aláez C, FERNANDEZ-ALÁEZ M, FRANKEN RJM, GARCÍACRIADO F, GROSS EM, GYLLSTRÖM M, HANSSON L-A, IRVINE K, JÄRVALT A, JENSEN J-P, JEPPESEN E, Kairesalo T, Kornijów R, Krause T, KÜNNAP H, LAAS A, LILl E, LORENS B, LUUP H, Miracle MR, Nõges P, NõGES T, NyKÄNEN M, Ott I, PeCzula W, PeEters ETHM, Phillips G, Romo S, Russell V, Salujõe J, Scheffer M, Siewertsen K, Smal H, Tesch C, Timm H, Tuvikene L, Tonno I, VirRo T, Vicente E \& WILSON D (2003). The determination of ecological status in shallow lakes - a tested 
system (ECOFRAME) for implementation of the European Water Framework Directive Aquatic Conservation: Marine and Freshwater Ecosystems, 13 (6):507-549.

NAKAGAWA S \& SCHIELZETH H (2013). A general and simple method for obtaining $\mathrm{R}^{2}$ from generalizes linear mixed-effects models. Methods in Ecology and Evolution, 4:133-142.

Nicola GG, Elvira B \& Almodóvar A (1996). Dams and fish passages facilities in the large rivers of Spain:effects on migratory species. Archiv für Hydrobiologie, Supplementband Large Rivers, 113 (10):375-379.

NOVOTNY V,BARTOŠOVÁA, O'REILLY N \& EHLINGER $\mathrm{T}$ (2005); Unlocking the relationship of biotic integrity of impaired waters to anthropogenic stresses. Water Research, 39:184-198.

PERSSON L (1983). Effects of intra- and interspecific competition on dynamics and size structure of a perch Perca fluviatilis and roach Rutilus rutilus. Oikos, 41:126-132.

Quataert P, Verschelde P, Breine J, Verbeke G, Goetghebeur E \& Ollevier F (2011). A diagnostic modelling framework to construct indices of biotic integrity:A case study of fish in the Zeeschelde estuary (Belgium). Estuarine, Coastal and Shelf Science, 94:222-233.

RAMM AEL (1990). Application of the community degradation index to South African estuaries. Water Research, 24 (3):383-389.

R Development Core TeAm (2012). R:A language and environment for statistical computing. Vienna, Austria. Available at http://www.R-project.org:R, Foundation for Statistical Computing.

RitTERBUSCH D, SCHUBERT M \& BRÄMICK U (2011). Lake Fish Milsestone 6 Report. In:Interkalibrierung und Fortentwickelung der fischbasierten Seen- und Fließgewässerbewertung gemäß EU-Wasserrahmenrichtline Project O 5.11, 82 pp. (in German and English)

SHIELDS FD JR., KNIGHT SS \& COOPER CM (1995). Use of the index of biotic integrity to assess physical habitat degradation in warmwater streams. Hydrobiologia, 312:191-208.

STEEDMAN RJ (1988). Modification and assessment of an index of biotic integrity to quantify stream quality in Southern Ontario. Canadian Journal of Fisheries and Aquatic Science, 45 (3):492-501.

VANDEKERKHOVE J, CARDOSOAC \& BOON PJ (2013). Is there need for a more explicit accounting of invasive alien species under the Water Framework Directive? Management of Biological Invasions, 4, open access, $12 \mathrm{pp}$.

VERREYCKEN H, ANSEEUW D, VAN THUYNE G, Quataert P \& Belpaire C (2007). The nonindigenous freshwater fishes of Flanders (Belgium): review, status and trends over the last decade. Journal of Fish Biology, 71 (Supplement D):160-172.

WANG L, LYONS J, KANEHL P \& BANNERMAN $R$ (2001). Impact of urbanization on stream habitat and fish across multiple spatial scales. Environmental Management, 28 (2):255-266.

Wetzel RG (1983). Limnology (2nd edition) Saunders College publishing, New York:255-297.

WHITTIER TR (1999). Development of IBI metrics for lakes in southern New England. In:Simon TP (ed), Assessing the Sustainability and Biological Integrity of Water Resources Using Fish Communities, CRC Press LLC, Washington DC:563-582.

WIŚNIEWOLSKI W \& PRUS P (2009). Preliminary criteria for ecological status assessment index for dam reservoirs on the basis of the ichthyofauna assemblages. Annals of Warsaw University of Life Sciences - SGGW, Land Reclamation, 41 (2):131-141.

Received: January 8th, 2014

Accepted: January 16th, 2015

Branch editor: Hilde Eggermont 


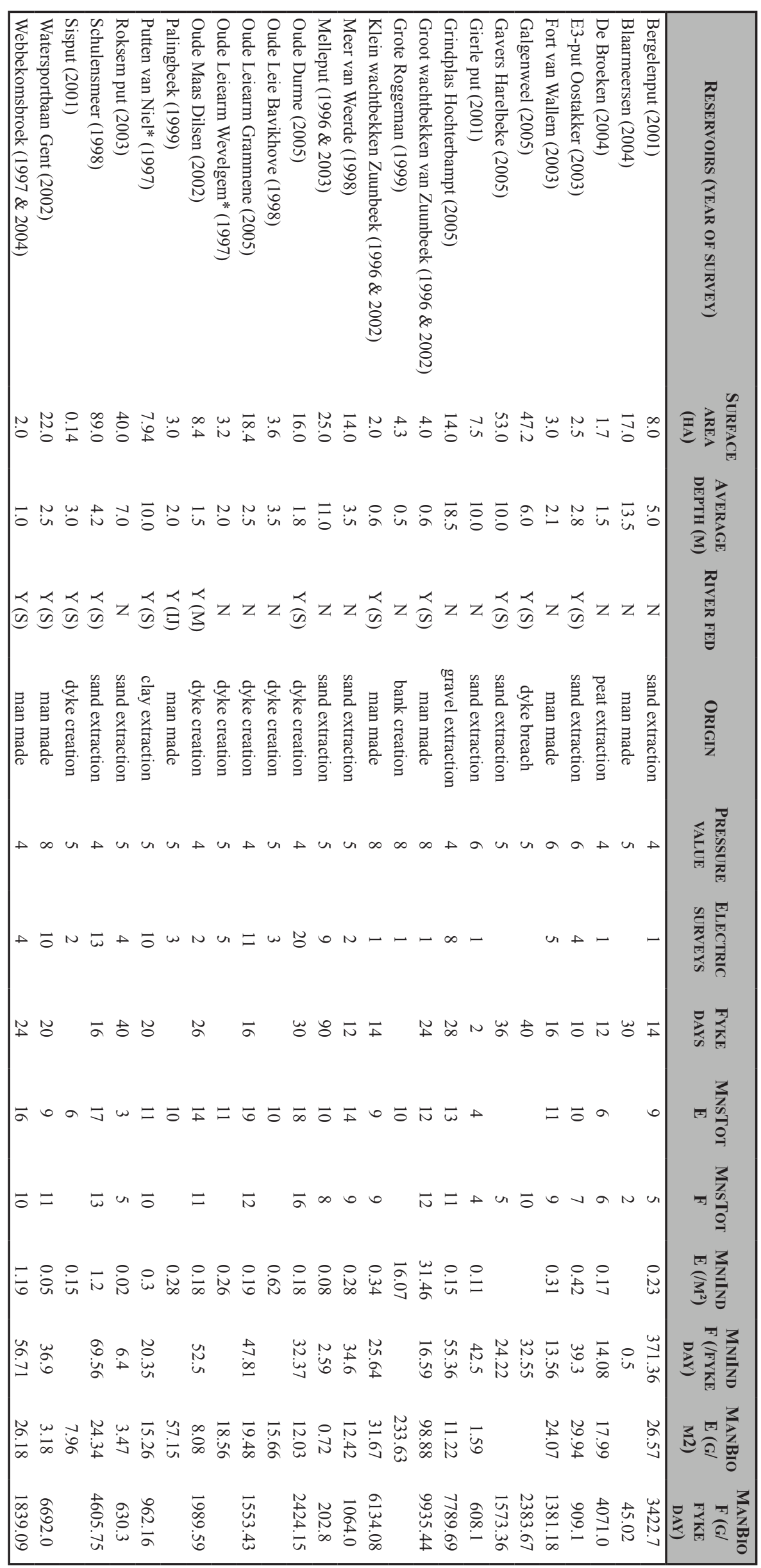

물요용 궁. 일.

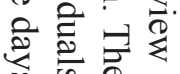
我家家 $\ddot{0} \stackrel{0}{0}$ के है 它

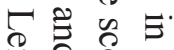
ब․

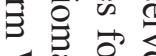
$\sum_{0}$

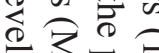
궁웅 हैं ᄋ휴 용 훌. क 造造营 ¿

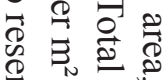
웅. .

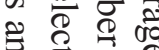
ㄹ. ‥ 声实 훙 居.

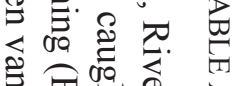
畄哭 고용

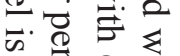

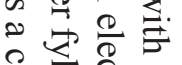
$\delta$ 응 망 产. 它员. 응. 옹 눙 遮芯芯 - 응 ज्ञ त्ञ Ш

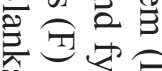

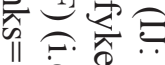
ठ를 훙

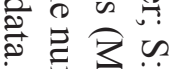

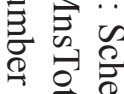

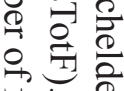
这寻管 㤩氺

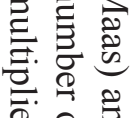
官。 
TABLE B

Recent fish data for reservoirs in Flanders (autumn 1996-2005). \# is the number of catches per species grouped over all surveys. Frequency is the catch frequency in the reservoirs (\#/campaigns). \# ind. gives the number of individuals caught in the reservoirs. Last column indicates if the species is a MEP/GEP species. Fyke days equals the number of fykes multiplied by the days they were standing; $n$ gives the number of electric surveys.

\begin{tabular}{|c|c|c|c|c|c|}
\hline \multirow{2}{*}{ Scientific name } & \multicolumn{2}{|c|}{ Fykes (520 fyke days) } & \multicolumn{2}{|c|}{$\begin{array}{l}\text { Electric fishing } \\
\quad(n=112)\end{array}$} & \multirow[b]{2}{*}{$\begin{array}{l}\text { MEP/ } \\
\text { GEP }\end{array}$} \\
\hline & frequency & \# ind. & frequency & \# ind. & \\
\hline Abramis brama (LINNAEUS, 1758) & 32.47 & 1918 & 36.60 & 116 & $\mathrm{X}$ \\
\hline Alburnus alburnus (LINNAEUS, 1758) & 0.43 & 1 & 1.31 & 2 & \\
\hline Ameiurus nebulosus (LESUEUR, 1819) & 6.93 & 487 & 5.88 & 343 & \\
\hline Anguilla anguilla (LINNAEUS, 1758) & 80.95 & 2193 & 86.27 & 3649 & $\mathrm{X}$ \\
\hline Blicca bjoerkna (LINNAEUs, 1758) & 29.44 & 802 & 28.1 & 477 & $\mathrm{X}$ \\
\hline Carassius carassius (LINNAEUS, 1758) & 0.43 & 1 & 3.92 & 8 & $\mathrm{X}$ \\
\hline Carassius gibelio $(\mathrm{BLOCH}, 1782)$ & 12.12 & 304 & 35.29 & 1154 & $\mathrm{X}$ \\
\hline Cobitis taenia (LINNAEUs, 1758) & 0.00 & 0 & 4.58 & 36 & \\
\hline Cyprinus carpio carpio (LINNAEUS, 1758) & 15.15 & 225 & 21.57 & 392 & $\mathrm{X}$ \\
\hline Esox lucius (LINNAEUS, 1758) & 5.19 & 16 & 49.67 & 563 & $\mathrm{X}$ \\
\hline Gasterosteus aculeatus (LINNAEUS, 1758) & 0.00 & 0 & 6.54 & 399 & $\mathrm{X}$ \\
\hline Gobio gobio (LINNAEUS, 1758) & 0.00 & 0 & 5.88 & 39 & $\mathrm{X}$ \\
\hline Gymnocephalus cernua (LINNAEUs, 1758) & 38.10 & 2776 & 35.95 & 455 & $\mathrm{X}$ \\
\hline Lepomis gibbosus (LINNAEUS, 1758) & 15.15 & 874 & 33.99 & 2238 & \\
\hline Leucaspius delineatus (HECKEL, 1843) & 0.87 & 3 & 11.11 & 195 & $\mathrm{X}$ \\
\hline Leuciscus idus (LINNAEUS, 1758) & 2.16 & 5 & 15.03 & 45 & $\mathrm{X}$ \\
\hline Liza ramada (RISSO, 1827) & 0.43 & 2 & 0.00 & 0 & \\
\hline Lota lota (LinNAEUs, 1758) & 0.0 & 0 & 0.00 & 0 & $\mathrm{X}$ \\
\hline Perca fluviatilis (LinNAEUs, 1758) & 60.17 & 6408 & 91.50 & 7577 & $X$ \\
\hline Platichthys flesus (LINNAEUS, 1758) & 6.06 & 21 & 3.27 & 9 & \\
\hline Pseudorasbora parva (TEMMINCK \& SCHLEGEL, 1846) & 6.93 & 96 & 9.80 & 431 & \\
\hline Pungitius pungitius (LINNAEUS, 1758) & 0.00 & 0 & 2.61 & 10 & $\mathrm{X}$ \\
\hline Rhodeus sericeus (PALLAS, 1776) & 6.06 & 160 & 18.95 & 1069 & $\mathrm{X}$ \\
\hline Rutilus rutilus (LINNAEUs, 1758) & 38.96 & 2700 & 79.08 & 8879 & $\mathrm{X}$ \\
\hline Salmo trutta (LINNAEUS, 1758) & 0.43 & 1 & 0.65 & 4 & \\
\hline Sander lucioperca (LINNAEUs, 1758) & 33.33 & 1836 & 15.69 & 65 & $X$ \\
\hline Scardinius erythrophthalmus (LINNAEUs, 1758) & 13.85 & 303 & 58.17 & 1666 & $\mathrm{X}$ \\
\hline Silurus glanis (LINNAEUS, 1758) & 0.00 & 0 & 0.00 & 0 & $\mathrm{X}$ \\
\hline Squalius cephalus (LINNAEUS, 1758) & 0.00 & 0 & 1.31 & 2 & \\
\hline Tinca tinca (LinNAEUs, 1758) & 15.58 & 59 & 43.14 & 541 & $\mathrm{X}$ \\
\hline
\end{tabular}




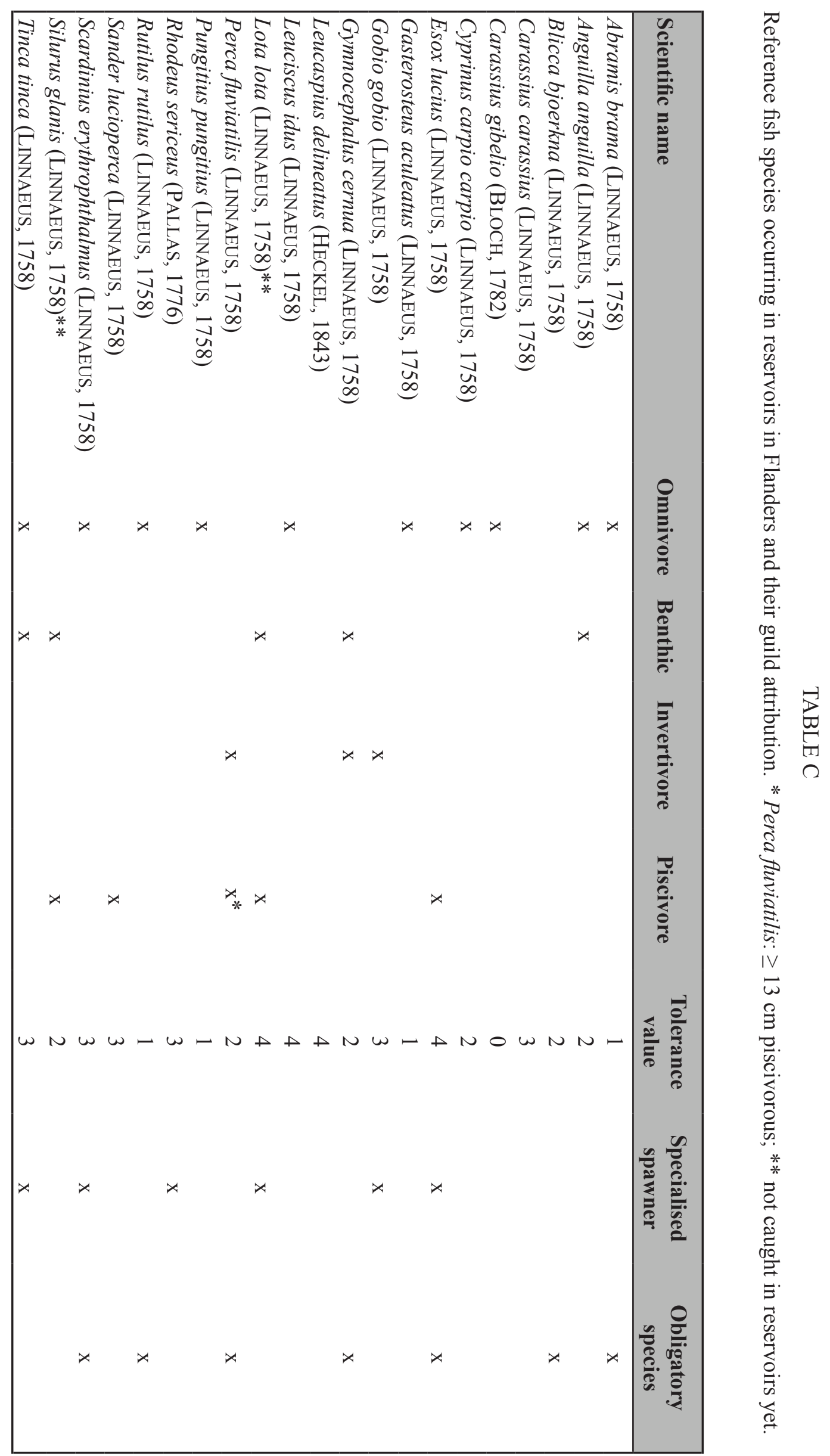

